\title{
Empirical Analysis of Users' Acceptance of Application-Based E-Money
}

\author{
Marcellia Susan
}

\begin{abstract}
Information Technology is currently experiencing growth which affects the consumers and companies' behaviors. Business holders are utilizing technologies in order to increase their business' competitive edge. The current technology growth also includes payment system growth. Technology development is currently decently fast paced such that financial transactions are also easier and faster. E-money works as a substitute for physical cash and as a system which made payments on goods and services possible. The objective of the study is to analyze certain factors which determine users' acceptance of application-based e-money. The samples of this study are application based e-money users. Data concerning perceived ease of use, perceived usefulness, perceived credibility, perceived enjoyment, amount of information, social influence, and behavioral intention to use application-based e-money are obtained through questionnaires. The collected data were processed to test the relationships between research variables. The results of the research analysis also show depictions of all the factors which affect users' acceptance of application-based e-money.
\end{abstract}

Keywords: Application-Based E-money; Users'Acceptance

\section{INTRODUCTION}

Rapid technology developments provide easy access to information. This change also makes it easier to make a transaction by applying sophisticated information technology. Even though technology has evolved over the years, however people need more time to accept and adopt the technology. People acceptance of new technology still is a challenge for the company (1). Payment instruments evolve along with technological advances and community needs. At the beginning of the payment instrument was known, the barter system was common in the pre-modern era. The payment instrument then develops using a certain unit that has a payment value known as money, and money is still the main payment instruments in the community. Furthermore, the payment instruments continue to grow along with the advancement of technology and community needs from cash-based to non-cash-based payment instruments.
The growth of electronic money (e-money) transactions in Indonesia is quite rapid from 2016 to 2018 compared to previous years. The increase of e-money using is supported by a government policy that requires toll gate payments to use e-money. Non-cash payments using e-money can speed up transactions that occur at toll gates. This government policy made the people have to use electronic money for toll gates payment. This is in line with the government's efforts to create a society (Less Cash Society) that uses non-cash instruments in their financial transactions (2). The increasing consumers' preference for non-cash based payments over cash-based payments covers paperless payments such as electronic transfer and card-based payments such as ATM and credit, debit, and prepaid card. The behavioral intention to use a certain information system determines technology adoption, and the system' perceived benefit and perceived ease of use affect the behavioral intention (3). The objective of the study is to analyze certain factors that determine the users' acceptance of application-based e-money. The study also tests the effects of all these factors on users' acceptance of application-based e-money.

\section{LITERATURE REVIEW}

E-money is a prepaid product in which a record of available funds is stored in the consumers' electronic devices (4). Registered e-money and unregistered e-money are the e-money types. (2). E-money using is expected to speed up transaction processes compared to cash.Based on the literature of technology acceptance model (5) and unified theory of acceptance and use of technology (6), perceived ease of use (PEOU), perceived usefulness (PU), social influence (SI), and perceived facilitating conditions reflect consumers' adoption readiness. The Technology Acceptance Model reveals that the desire to use a system is influenced by PEOU and PE of the system (7). The intensity of usage and interaction between the user and the system can also show the ease of use. Based on the Technology Acceptance Model, Intention to Use affects a system' Actual Use (6), (8), (9), (10), (11). Perceived credibility (PC) related to privacy and security issues has an impact on Behavioral Intention (BI) (3), which means that perceived credibility can direct the intention to use information technology products, including e-money. Another factor which can affect Behavioral Intention is Social Influence. 


\section{Empirical Analysis of Users' Acceptance of Application-Based E-Money}

Perceived enjoyment (PE) describes the perception of an individual pertaining to pleasure feeling in adopting new technology (1), and it is added in Technology Acceptance Model (12). The relationship between PE and BI is supported by the previous studies results (1), (13). Previous research related to online banking shows that PEOU, PU, PE, security, privacy, and information influence intention to use mobile banking. In this case, the amount of information (AOI) that consumers have is the major factor that affects online banking users' acceptance (14). The study develops a model (Fig. 1) indicating the users' acceptance of application-based e-money which consists of six independent factors that are hypothesized affect the users' acceptance.Based on the theoretical framework and previous researches, the research hypotheses are: H1: PEOU, PU, PC, PE, AOI, and SI simultaneously affect BI to Use Application-based E-money $\mathrm{H} 2$ : PEOU, PU, PC, PE, AOI, and SI partially affect BI to Use Application-based E-money

\section{METHODOLOGY}

The main constructs of this study are PEOU, PU, PC, PE, AOI, SI, and Users' Acceptance of application-based e-money which is measured by BI. The data were collected through an anonymous survey conducted in Bandung, West Java, Indonesia. The population of this research is application-based e-money users. Sampling is conducted using the criteria of e-money users who have used application-based e-money for the past half year. Sampling determination is conducted using the criteria of e-money users who have used application-based e-money for the past half year. A total of 282 data were collected from questionnaire distribution. This study used a four-point scale, which is ranging from strongly agree to strongly disagree. The questionnaire consists of 18 closed-ended questions. This study used multiple regression, F-test, and t-test as a data processing tool which examine the causal relationships between the constructs empirically. A descriptive analysis also was conducted to clarify the PEOU, PU, PC, PE, AOI, SI, and Users' Acceptance of application-based e-money.

\section{RESULTS AND FINDINGS}

The data were collected from application-based e-money users in Bandung, Indonesia, and a total of 282 data concerning PEOU, PU, PC, PE, AOI, SI, and BI to use application-based e-money were obtained from questionnaires distribution. The validity of the measurement was examined using correlation coefficient, and validity was given for all constructs since all the correlation coefficients exceed the minimum threshold values suggested in the literature $(0.3)$. The reliability of the instrument was tested using Cronbach's alpha coefficients, and the results show that the instrument has moderate reliability with the coefficients were exceed 0.60 . Table 1 and 2 provide an overview of the measurements of this study. The data processing was conducted to get a depiction of the users' acceptance of application-based e-money and the factors that determine it. The average score of the respondent's responses was used to see how respondents respond to each of the variables used in this study. The analysis results show that the mean of the respondents' response of Ease of Use for Transactions and Easy to Understand Usage are 3.65 and 3.57, respectively. E-money users feel that e-money based applications are easy to use and understand. The analysis of PU shows that e-money users perceive that application-based e-money simplifies and speeds up payments. It is also cheaper and minimizes mistakes. It is supported with an average value of $3.59,3.38,3.41$, and 3.39 respectively of each item. Among all items used to measure PU, the highest benefit value comes from the simplicity of payment. For the PC variable, the mean of each item is $3.05,3.05,3.26$, and 2.58 which indicates that e-money users perceive that e-money users still are not entirely sure of the credibility of application-based e-money, especially related to the security of private information.

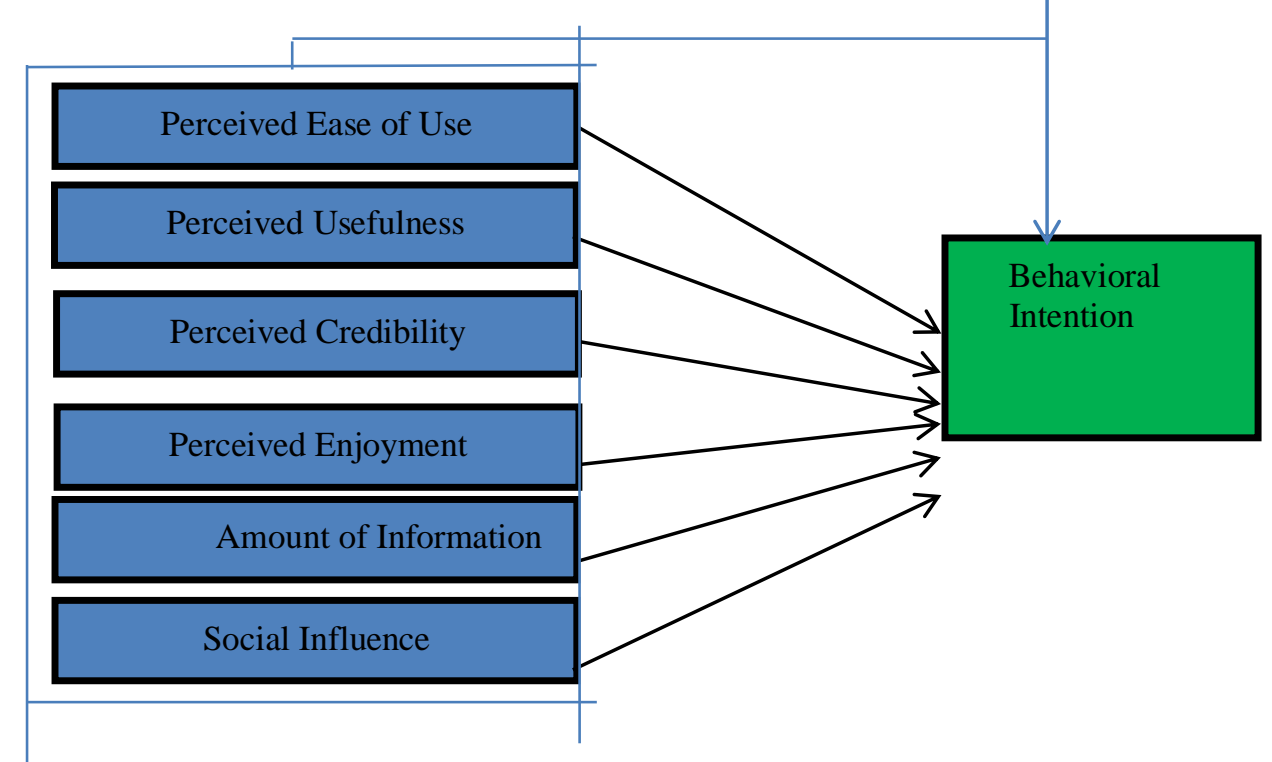

Fig. 1: Research Model

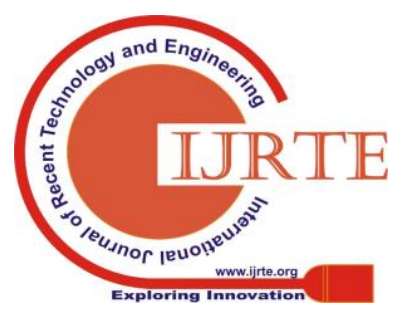


Table 1: Reliability Measurement

\begin{tabular}{|c|c|}
\hline Variables & Coefficient \\
\hline PEOU & .627 \\
\hline PU & .772 \\
\hline PC & .657 \\
\hline PE & .735 \\
\hline AOI & .654 \\
\hline SI & .718 \\
\hline BI & .653 \\
\hline
\end{tabular}

Table 2: Validity Measurement

\begin{tabular}{|c|c|c|}
\hline \multicolumn{2}{|r|}{ PEOU } & Correlation \\
\hline 1 & Ease of use for transactions & .458 \\
\hline 2 & Easy to understand usage & .458 \\
\hline \multicolumn{2}{|r|}{$\mathrm{PU}$} & \\
\hline 3 & Simpler payment & .569 \\
\hline 4 & Faster payment & .512 \\
\hline 5 & Minimize errors & .544 \\
\hline 6 & Cheaper payment & .704 \\
\hline \multicolumn{2}{|r|}{ PC } & \\
\hline 7 & Sense of security & .354 \\
\hline 8 & Safety assurance & .570 \\
\hline 9 & $\begin{array}{c}\text { Guarantee the payment process is } \\
\text { going well }\end{array}$ & .518 \\
\hline 10 & Private information security & .321 \\
\hline \multicolumn{2}{|r|}{$\mathrm{PE}$} & \\
\hline 11 & Provide lot of enjoyment & .584 \\
\hline 12 & Provide lot of excitement & .584 \\
\hline \multicolumn{2}{|r|}{ AOI } & \\
\hline 13 & $\begin{array}{c}\text { Information about using } \\
\text { application-based e-money }\end{array}$ & 486 \\
\hline 14 & $\begin{array}{l}\text { Information about the benefit of } \\
\text { using application-based e-money }\end{array}$ & .486 \\
\hline \multicolumn{2}{|r|}{ SI } & \\
\hline 15 & $\begin{array}{l}\text { Family and/ friends are using } \\
\text { application-based e-money }\end{array}$ & .564 \\
\hline 16 & $\begin{array}{l}\text { Family and/ friends are } \\
\text { recommending the use of } \\
\text { application-based e-money }\end{array}$ & .564 \\
\hline \multicolumn{2}{|r|}{ BI } & \\
\hline 17 & $\begin{array}{l}\text { Intention to use application-based } \\
\text { e-money in addition to cash }\end{array}$ & .486 \\
\hline 18 & $\begin{array}{l}\text { Intention to use application-based } \\
\text { e-money instead cash }\end{array}$ & .486 \\
\hline
\end{tabular}

Analysis of PE variable shows that e-money users perceive that application-based e-money relatively provides a lot of enjoyment and a lot of excitement with an average value of 3.30 and 3.42, respectively. Of the two items of AOI variable, e-money users perceive and give the scores which are slightly below three of the scale of four (2.87 and 2.83) for Information about the Benefit and Usage of application-based e-money. The same thing applies to one of the items of SI variable as the mean is 2.83 for Families and/ Friends are Using Application-based E-money. The results also show that families and/ friends recommend the use of application-based e-money, with a score of 3.11. Based on e-money users' BI analysis of two modified indicators (15), the study reveals users' acceptance of application-based e-money. They have an intention to use it in addition, or instead of cash, as the score is 3.21 and 3.35 respectively. The multiple regression analysis was conducted to reveal the effect of different factors on users' acceptance of application-based e-money. The results of the multiple regression analysis are presented in Table 3 and 4 . The simultaneous test results using the ANOVA test in table 3 show a significance value (sig) of 0.000 which is smaller than the alpha value (0.05). It can be said that simultaneously, PEOU, PU, PC, PE, AOI, and SI have an effect on BI to Use Application-based E-money. Table 4 shows that the significance value of $\mathrm{PC}$ on $\mathrm{BI}$ is 0.003 , which is smaller than alpha value (0.05), so that it can be said that the PC statistically significant and has a positive effect on BI. The results also show that $\mathrm{PE}$ and $\mathrm{AOI}$ statistically significant and has a positive influence on BI with significance value 0.075 (alpha value 0.10 ), and 0.000 (alpha value 0.05 ) respectively. Even though all the independent variables simultaneously have an impact on behavioral intention of using application-based e-money, the study shows that PEOU, PU, and SI, partially do not have an impact on Behavioral Intention. In this case, young people as e-money users are familiar and close to technology and they understand technological developments throughout their daily lives. Their acceptance of e-money is more influenced by the enjoyment of using e-money, the information about e-money, and personal information credibility. In this case, the results of this study do not support previous studies that show that PU and PEOU positively influence users' intention to use (16), (17), (18), (19). However, the previous study supported the results of this study regarding the effect of PE (1), (20), and PC (3) on behavioral intention. The magnitude of the simultaneous influence of PEOU, PU, PC, PE, AOI, and SI simultaneously on BI to Use Application-based E-money can be seen by the value of Adjusted R-square 0.312. This result is presented in Table 5 .

\section{CONCLUSION}

The study was able to reveal that users' acceptance of application-based e-money as measured by $\mathrm{BI}$ is simultaneously affected by PEOU, PU, PC, PE, AOI, and SI. $\mathrm{PE}, \mathrm{PC}$, and AOI related to application-based e-money partially have a positive effect on their acceptance.

The findings also indicate that users' acceptance is partially not affected by PEOU, PU, and SI. The insignificance of these factors might be attributed to the respondents' characteristics who are mostly young, and they generally have an understanding of technological developments. They might understand enough the benefits of application-based e-money and have no difficulties in using it. The results of the study provide application based e-money providers of information about factors which can affect e-money users' acceptance. In the planning and development of application based e-money, the provider needs to have a focus on informative content that relevant to $\mathrm{PE}, \mathrm{PC}$, and AOI that can be accessed by e-money users. Future study may consider other related variables that might affect or be affected by users' acceptance of application-based e-money

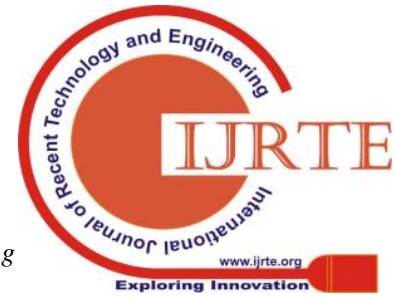




\section{Empirical Analysis of Users' Acceptance of Application-Based E-Money}

Table 3: Regression Analysis - ANOVA

\begin{tabular}{|ll|r|r|r|r|r|}
\hline \multicolumn{1}{|l|}{ Model } & Sum of Squares & \multicolumn{1}{|c|}{ df } & Mean Square & F & \multicolumn{1}{c|}{ Sig. } \\
\hline 1 & Regression & 304.801 & 6 & 50.800 & 22.256 & $.000^{\circ}$ \\
& Residual & 627.685 & 275 & 2.282 & & \\
Total & 932.486 & 281 & & & \\
\hline
\end{tabular}

Table 4: Regression Analysis - Coefficient

\begin{tabular}{|c|c|c|c|c|c|c|}
\hline \multirow{2}{*}{\multicolumn{2}{|c|}{ Model }} & \multicolumn{2}{|c|}{$\begin{array}{l}\text { Unstandardized } \\
\text { Coefficients }\end{array}$} & \multirow{2}{*}{\begin{tabular}{|c|}
$\begin{array}{l}\text { Standardized } \\
\text { Coefficients }\end{array}$ \\
Beta \\
\end{tabular}} & \multirow[b]{2}{*}{$\mathrm{t}$} & \multirow[b]{2}{*}{ Sig. } \\
\hline & & \begin{tabular}{|l|} 
\\
\end{tabular} & Std. Error & & & \\
\hline & (Constant) & 4.574 & 1.283 & & 3.564 & .000 \\
\hline & VAR00001 & -.022 & .116 & -.010 & -.187 & .851 \\
\hline & VAR00002 & .028 & .058 & .030 & .487 & .627 \\
\hline & VAR00003 & .254 & .086 & .168 & 2.949 & .003 \\
\hline & VAR00004 & .169 & .095 & .103 & 1.788 & .075 \\
\hline & VAR00005 & .686 & .086 & .455 & 7.950 & .000 \\
\hline & VAR00006 & -.020 & .125 & -.009 & -.163 & .871 \\
\hline
\end{tabular}

Table 5: Regression Analysis - Model Summary

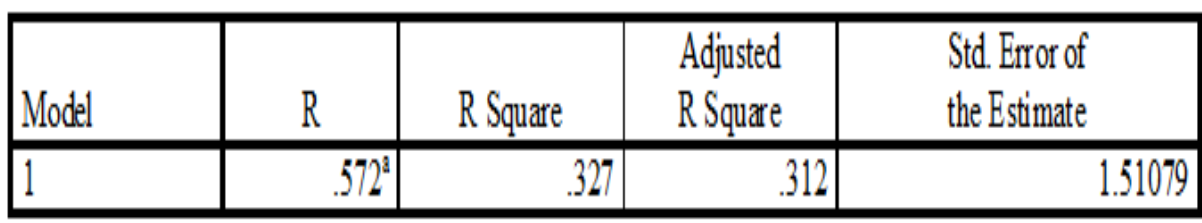

14.Pikkarainen, T., Pikkarainen, K., Karjaluoto, H., \& Pahnila, S. (2004) Consumer Acceptance of Online Banking: An Extensionof The Technology Acceptance Model. Internet Research, 14(3):224-235.

\section{REFERENCES}

1. Cheema, U., Rizwan, M., Jalal, R., Durrani, F., \& Sohail, N. (2013). The Trend of Online Shopping in 21st Century: Impact of Enjoyment in TAM Model. Asian Journal of Empirical Research, 3(2):131-141

2. Bank Indonesia. (2014). Retrieved from https://www.bi.go.id.

3. Wang, Y., Wang, Y., Lin, H., \& Tang, T. (2003). Determinants of user acceptance of Internet banking: an empirical study. International Journal of Service Industry Management, Vol. 14 Iss: 5 pp. $501-519$.

4. Survey of Electronic Money Developments. (2000, May 24). Retrieved from Bank for International Settlements: https://www.bis.org/cpmi/publ/d38.htm

5. Davis, F., \& Arbor, A. (1989). Perceived usefulness, perceived ease of use, and user acceptance of information technology. MIS Quarterly, V 13 (3,), 319-39.

6. Venkatesh, V., Morris, M., Davis, G., \& Davis, F. (2003). User acceptance of information technology: toward a unified view. MIS Quarterly, Vol. 27 No. 3, pp. 425-478.

7. Patel, K., \& Patel, H. (2016). Adoption of internet banking services in Gujarat: an extension of TAM with perceived security and social influence. International Journal of bank Marketing .

8. Al-Bakri, A., \& Katsioloudes, M. (2015). The factors affecting e-commerce adoption. Management Research Review, Vol. 38 Issue: 7 , pp.726-749.

9. Djajadikerta, H., Susan, M., \& Djajadikerta, R. (2017). Antecedents of Customer Intention in Using Online Shared Motorcycle Taxi Service in Indonesia. Advanced Science Letters, Volume 23, Number 9,

10.Djajadikerta, H., \& Susan, M. (2017). Driving Factors and Inhibiting Factors in Adopting Electronic Tax Filing in Indonesia. Advanced Science Letters, Vol.23(8), pp.7569-7573.

11.Özkan, S., Bindusara, G., \& Hackney, R. (2010). Facilitating the adoption of e-payment systems: theoretical constructs and empirical analysis. Journal of Enterprise Information Management, Vol. 23, Issue: 3, pp.305-325.

12.Liao, C., Tsou, C., \& Shu, Y. (2008). The Roles of Perceived Enjoyment and Price Perception in Determining Acceptance of Multimedia-on-Demand. International Journal of Business and Information, 3(1):27-52.

13.Chin, L., \& Ahmad, Z. (2015). Perceived Enjoyment and Malaysian Consumers' Intention to Use A Single Platform E-Payment. SHS Web of Conferences 18 (pp. 1-9). Hanoi \& Ha Long Bay: EDP Sciences. pp. 8617-8622(6)

15.Çelik, H. (2011). Influence of social norms, perceived playfulness and online shopping anxiety. International Journal of Retail \& Distribution Management, Vol. 39 Issue: 6, pp.390-413.

16.Hubert, M., Blut, M., Brock, C., Zhang, R., Koch, V., \& Riedl, R. (2018). The influence of acceptance and adoption drivers on smart home usage. European Journal of Marketing.

17.Kallanmarthodi, G., \& Vaithiyanathan, M. (2012). Assessment of a Modified Technology Acceptance Model among e-banking customers in Coimbatore City. international Journal of Innovation, Management and Technology, Vol.3(2):181-187.

18.Lai, Y.-H. (2012). The Study of Tehcnology Acceptance for E-Wallets Application of Clinic Fees Payment. Health, Vol. 4, No.11, 1082-1087.

19.Omol, E., Abeka, S., \& Wauyo, F. (2017). Factors Influencing Acceptance of Mobile money Applications in Enterprise Management: A Case Study of Micro and Small Enterprise Owners in Kisumu Central Business District, Kenya. International Journal of Advanced Research in Computer and Communication Engineering, Vol. 6, Issue 1.

20.Cheng, Y. (2014). Exploring the intention to use mobile learning: the moderating role of personal innovativeness. Journal of Systems and Information Technology, Vol.16(1):40-61.

\section{AUTHOR PROFILE}

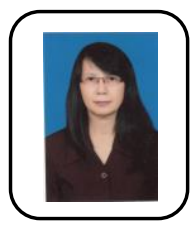

Marcellia Susan is a Professor at Department of Management, Faculty of Economics, Maranatha Christian University, Bandung, West Java, Indonesia. She has received her Undergraduate degree in Management, Post-graduate degree in Industrial Management, and Doctoral degree in Business Management. She has done many researches in various topics on Management Study. She can be contacted at marcellia.susan@gmail.com.

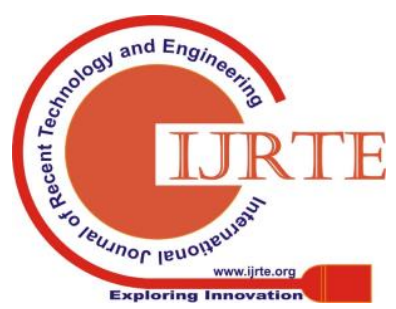

